REFLEKSI HUKUM

Jurnal Ilmu Hukum
p-ISSN 2541-4984 | e-ISSN 2541-5417

Volume 3 Nomor 1, Oktober 2018, Halaman 17-32

DOI: https://doi.org/10.24246/jrh.2018.v3.i1.p17-32

Open access at: http://ejournal.uksw.edu/refleksihukum

Penerbit: Fakultas Hukum Universitas Kristen Satya Wacana

\title{
FILANTROPI DAN PELAYANAN RUMAH SAKIT BERBASIS GEREJAWI DALAM PERSPEKTIF HUKUM
}

\author{
Dyah Hapsari Prananingrum \\ Fakultas Hukum Universitas Kristen Satya Wacana \\ Korespondensi: dyah.prananingrum@gmail.com
}

\begin{abstract}
Abstrak
Era desentralisasi kesehatan dan era jaminan kesehatan nasional merupakan tantangan bagi layanan kesehatan dan rumah sakit yang diselenggarakan oleh lembaga nirlaba. Salah satu lembaga nirlaba yang menyelenggarakan perumahsakitan adalah gereja. Dalam sejarah Indonesia rumah sakit berbasis gereja telah banyak berperan di bidang pelayanan kesehatan. Strategi rumah sakit untuk menjadi pilihan bagi masyarakat harus dikembangkan ke arah peningkatan kualitas layanan, menuju rumah sakit yang cerdas, aman, ramah, memiliki fasilitas dan infrastruktur pendukung canggih dan terkini, dengan mematuhi prinsip manajemen dan operasi yang efektif dan efisien. Selain itu, juga diperlukan sumber pendanaan yang kuat. Filantropi sebagai alternatif pendanaan harus dikembangkan. Undang-undang memungkinkan untuk mengumpulkan dana rumah sakit melalui filantropi ini.
\end{abstract}

Kata Kunci: Hukum Indonesia; Rumah Sakit; Filantropi.

\begin{abstract}
The era of health decentralization and the era of national health insurance are the challenges for health services and hospitals organized by non-profit institutions. One of the non-profit institutions that hold hospitals is church. In history, Indonesia's church-based hospitals have supported a lot in the field of health services. The strategy done by hospitals in order to be chosen by community must be developed and set in the direction to improve the quality of services, and consequently to be a smart, safe, and friendly hospitals. Also, it ought to maintain sophisticated and up-to-date supporting facilities and infrastructure and it must comply with effective and efficient management and operations principles. In addition, a strong funding sources are needed. A philanthropy may be necessary to conduct as an alternative fund while the existing laws permit the scheme of the philanthropy fund.
\end{abstract}

Keywords: Indonesia Law; Hospital; Philanthropy. 


\section{PENDAHULUAN}

Memasuki era desentralisasi kesehatan tahun 2000, dan juga era Jaminan Kesehatan Nasional (JKN) menjadi tantangan tersendiri bagi pelayanan kesehatan dan rumah sakit. Target pemerintah untuk mencapai Universal Health Coverage (UHC) pada 2019 perlu dipersiapkan sejak dini oleh rumah sakit di Indonesia. Selain bergabungdengan Badan Penyelenggara Jaminan Sosial (BPJS) Kesehatan, layanan kesehatan dan rumah sakit harus meningkatkan mutu layanan sehingga menjadi pilihan masyarakat dalam mengakses layanan kesehatan. Beberapa strategi harus dilakukan guna meningkatkan mutu dan pelayanan kesehatan dan perumahsakitan yang dibutuhkan oleh masyarakat. Rumah sakit yang memenuhi kriteria smart, safety, ramah, aman, bermutu, harus memiliki sarana prasarana yang mendukung serta menerapkan operasional yang efektif dan efisien menjadi syarat rumah sakit dalam era JKN. Agar dapat mencapai hal itu semua, dalam konteks sekarang setiap rumah sakit membutuhkan sumber daya manusia yang profesional, teknologi informasi yang handal, dan tentu saja semua itu membutuhkan dana yang mencukupi.

Bagaimana dengan rumah sakit yang didirikan oleh gereja, yang nota bene merupakan perpanjangan tangan diakonia terhadap masyarakat? Tantangan yang sama pasti dihadapi oleh rumah sakit dalam realita pelaksanaan karya kesaksian dan pelayanan. Terlebih manakala tuntutan terhadap layanan kesehatan sedemikian tinggi, regulasi yang terus berubah dan pengawasan oleh pemerintah semakin ketat dalam betuk akreditasi rumah sakit. Untuk memenuhi tuntutan layanan maka rumah sakit yang berbasis gereja akan diperhadapkan pada tuntutan yang sama atas sumber daya manusia yang profesional, teknologi dan informasi yang cepat, dalam dan tepat, yang semua hal tersebut membutuhkan sumber dana yang kuat. Namun di sisi yang lain sebenarnya ada peluang-peluang yang dapat dipilih guna menghadapi tantangan-tantangan tersebut dengan menggunakan sumber-sumber yang legal.

Rumah sakit umum (penulis: demikian pula rumah sakit berbasis gereja), memiliki sumber daya yang merupakan pendapatan operasional yang berasal dari masyarakat umum yang memanfaatkan fasilitas pelayanan kesehatan yang ada di rumah sakit. ${ }^{1}$ Adapun fasilitas rumah sakit yang dimaksudkan di atas antara lain pelayanan rawat jalan, pelayanan rawat inap, pelayanan gawat darurat, pelayanan penunjang medik, pelayanan kefarmasian dan lain-lain. Selain itu pembiayaan rumah sakit bersumber dari penerimaan rumah sakit sebagaimana disebutkan di atas, dapat juga berasal dari anggaran Pemerintah, subsidi Pemerintah, anggaran Pemerintah Daerah, subsidi Pemerintah Daerah atau sumber lain yang tidak mengikat sesuai dengan ketentuan peraturan perundang-undangan. ${ }^{2}$ 
Sumber lain yang tidak mengikat sebagaimana diatur dalam Pasal 48 (1) UU No. 44 Tahun 2009 tentang Rumah Sakit tidak diatur secara jelas. Dengan demikian dimungkinkan rumah sakit untuk "berkreasi" dalam mencari sumber pembiayaan rumah sakit dengan batasan bahwa sumber itu tidak mengikat dan sesuai dengan ketentuan peraturan perundang-undangan.

Salah satu sumber pembiayaan yaitu dengan membentuk dan menguatkan sinergi antara gereja dan perumahsakitan dalam pembiayaan rumah sakit, untuk menyatakan kesaksian dan pelayanan dibidang kesehatan. Bagaimanakah bentuk sinergi tersebut yang memungkinkan pembiayaan rumah sakit berbasis gereja dapat terwujud? Sebelum menjawab masalah tersebut, terlebih dahulu harus dipaparkan filosofi layanan rumah sakit berbasis gereja yang tentu berbeda karakternya dengan rumah sakit swasta yang lain, serta paparan tentang hubungan hukum gereja dengan rumah sakit.

\section{PEMBAHASAN}

\section{Filosofi Layanan Perumahsakitan Sebagai Media Kesaksian dan Pelayanan Gerejawi}

Gereja dibangun untuk memenuhi kebutuhan spiritual dalam suatu masyarakat yang menganut iman Kristen. Dalam perspektif teologis menurut Injil Yohanes, Gereja merupakan persekutuan orang-orang yang dipanggil keluar dari, dan sekaligus juga diutus ke dalam marturia dan koinonia. Diakonia sebagai salah satu dari 3 tugas gereja dunia (Yohanes 20:21). Dengan demikian yang dipandang sebagai Gereja merupakan persekutuan umat Tuhan, yang secara harafiah bukanlah sebuah gedung Gereja. Hal ini membuat esensi Gereja sejatinya dipandang sebagai suatu hal yang imanen atau tidak bertumpu pada hal yang bersifat harafiah.

Gereja sebagai suatu organisasi yang berbeda dengan organisasi pada umumnya, memiliki karakteristik yang berbeda dengan organisasi yang lain, dan juga merupakan suatu "organisme yang hidup dalam artian terus bergerak dan berkembang" serta memiliki kedudukan dan fungsinya tertentu. Secara filosofis teologis, gambaran tersebut dapat dipahami dalam 1 Petrus 2 : 9 "Tetapi kamulah bangsa yang terpilih, imamat yang rajani, bangsa yang kudus, umat kepunyaan Allah sendiri, supaya kamu memberitakan perbuatan-perbuatan yang besar dari Dia, yang telah memanggil kamu keluar dari kegelapan kepada terang-Nya yang ajaib". Gereja dipandang sebagai "kawan sekerja" (sunergo) Allah yang memiliki konsekuensi ganda yaitu ke dalam dan keluar. Artinya, di dalam dan melalui gereja pekerjaan penyelamatan Allah bagi manusia harus diejawantahkan. ${ }^{3}$ Anugerah keselama-tan dapat diterima melalui fiman Tuhan. Anugerah keselamatan yang adalah holistik, serta mengatasi ruang dan waktu, dan tentu saja merupakan hal yang sangat penting bagi setiap orang. Gereja memiliki tri tugas yaitu diakonia, mempunyai arti melayani. Secara harafiah, kata diakonia berarti memberi

\footnotetext{
3 Bambang Subandrijo, 'Layanan Kesehatan dan Perumahsakitan sebagai Media Kesaksian dan Pelayanan Gerejawi’ (Seminar Sinode GKJ-YLPHS, Salatiga, Desember 2018).
} 
pertolongan atau pelayanan. Dalam bahasa Ibrani berarti pertolongan, penolong, ezer sebagaimana dimuat dalam Alkitab, Kejadian 2:18 dan 20 serta Mazmur 121:1. Diakonia dalam bahasa Ibrani disebut syeret yang artinya melayani. Dalam terjemahan bahasa Yunani, kata diakonia disebutkan diakonia (pelayanan), diakonein (melayani), dan diakonos (pelayan).

Diakonia dalam pelayanan gerejawi dalam sejarah gereja tidak hanya terbatasi dalam gedung gereja. Pelayanan di bidang kesehatan misalnya telah dilakukan melalui klinik, balai pengobatan maupun rumah sakit yang sudah sangat "tua" sejalan dengan kesaksian dan pelayanan yang dilakukan gereja di tengah masyarakat. Pelayanan kesehatan dan perumahsakitan berbasis gerejawi ini bisa ditemukan hampir di seluruh wilayah Indonesia.

Dalam perkembangan jaman, rumah sakit berbasis gerejawi yang adalah rumah sakit Kristen dapat diartikan sebagai kepanjangan dari tangan gereja dalam kesaksian dan pelayanan. Seperti tiga ujung tombak pekabaran injil gereja di masa lalu, masa kini dan masa datang, karena layanan kesehatan dan perumahsakitan merupakan salah satu panggilan gereja dalam upaya penyembuhan yang mengutuhkan.

Berdirinya rumah sakit gerejawi pun dilandasi oleh dasar-dasar filosofis gerejawi, sebagaimana yang termuat dalam anggaran dasar dan anggaran rumah tangga yayasan. ${ }^{4}$ Rumah sakit berbasis gerejawi ini merupakan monitoring dan evaluasi pengelolaan lembaga-lembaga kepanjangan tangan- lembaga sosial gerejawi yang memiliki visi untuk terwujudnya manusia dan lingkungan yang sehat sejahtera, sebagai bagian dari perwujudan karya penyelamatan Allah tanpa membedakan suku, bangsa, agama, dan kepercayaan, golongan, budaya, sosial-ekonomi, serta jenis kelamin.

Jelas bahwa pada hakikatnya rumah sakit bersifat gerejawi merupakan kepanjangan tangan gereja, khususnya di bidang pelayanan kesehatan, sebagai salah satu bentuk perwujudan nyata damai sejahtera Allah bagi umat manusia, khususnya masyarakat Indonesia.

Secara teologis, gereja memiliki otoritas atas lembaga kesehatan yang menjadi kepanjangan tangannya. Berwenang memberi kejelasan mandat kepada lembaga perumahsakitan, sehingga lembaga tersebut memiliki pedoman akan tata hubungan (tata kelolanya) sebagai lembaga gerejawi. Berdasar iman dan pedoman yang jelas, lembaga perumahsakitan akan mampu terus bertumbuh dan berkembang menjadi sebuah organisasi dengan dasar iman Kristen, yang menjunjung tinggi asas transparansi, independensi, akuntabilitas, responsibilitas, serta kejujuran. Penjelasan ini merupakan wibawa dari sebuah rumah sakit yang bersifat gerejawi.

Berkembangnya rumah sakit bersifat gerejawi tidak terlepas dari peran suatu gereja. Gereja atau representasinya, tidak boleh gamang untuk terlibat dalam perencanaan, mengawal implementasinya, melakukan nya. Otoritas gereja dapat didayagunakan sedemikian rupa, sehingga

$4 \quad$ Dyah Hapsari Prananingrum, Hukum Yayasan di Indonesia (Genta Publishing 2016) 119. 
berfungsi efektif dalam memberikan motivasi, mengawasi, dan memajukan pelayanan lembaga kesehatan dan perumahsakitan sebagai "kepanjangan tangan" pelayanannya. Efektivitas hubungan yang mengikat gereja dan lembaga kesehatan serta perumahsakitan memerlukan revitalisasi dalam berbagai segi, diantaranya adalah nilainilai bersama, budaya dan tata laku, strategi bersama, tata kelola yang baik, dan memperhatikan seksama legalitasnya sebagai sebuah entitas hukum yang sah untuk menjalankan kegiatan perumahsakitan.

Adapun tantangan rumah sakit berbasis gerejawi yang harus dihadapi, sebagaimana desentralisasi kesehatan sejak tahun 2000 dan era JKN, merupakan tantangan bagi perumahsakitan yag berbasis gerejawi yang nota bene bersifat nirlaba. Di sisi lain tuntutan di era JKN saaat ini sedemikian tinggi sehingga perlu dikembangkannya strategi, menuju rumah sakit yang smart, safety, ramah, aman, dengan sarana-prasarana pendukung canggih, ditopang asas efektivitas dan efisiensi.

Pentingnya profesionalitas dalam menghadapi tantangan dan mengambil peluang. Secara operasional, profesionalitas manajemen dan kinerja lembaga kesehatan dapat dilihat dari proses kerja, sumber daya manusia, dan faktor-faktor pendukung yang dimiliki. Hal-hal yang perlu dicermati, seperti; keterbatasan sumber daya manusia (baik dari sisi kuantitas, kualitas, maupun profesionalitas), dukungan sistem (termasuk tata kelola dan sistem pengawasan) yang handal, ketersediaan sarana dan prasarana yang memadai, peralatan medis mutakhir yang up to date, dan ketersediaan dana.

Yayasan penyelenggara rumah sakit perlu berupaya menangkap, menciptakan dan memanfaatkan berbagai peluang yang ada untuk mengembangkan pelayanannya. Peran organ yayasan, pimpinan-pimpinan unit layanan, dan para pelaksana di lapangan yang merupakan eksekutor kebijakan, rencana strategis dan rencana operasional, sangat penting. Untuk mengoptimalkannya, masing-masing pihak harus menyadari domain dan batas-batas tanggung jawabnya. Di samping itu perlu kejelasan arah sebagai panduan kerja dan kesatuan langkah yang harmonis. Selain itu, sinergitas antara normative management, strategic management dan operative management perlu mendapatkan perhatian, agar pengembangan pelayanan dapat berjalan secara optimal. Di samping profesionalitas terdapat beberapa faktor yang mempengaruhi profesionalitas seperti:

'professional aptitude (kecerdasan/ ketangkasan profesional), professional knowledge (pengetahuan profesional), professional skill (keterampilan profesional), professional attitude (sikap profesional). Seorang profesional akan bertanggungjawab, berusaha keras untuk berbuat yang terbaik dan menjadi yang terbaik sesuai dengan profesinya. Ia tidak akan bosan belajar, mengikuti training, seminar, workshop, seminar, workshop, atau kursuskursus yang berhubungan dengan profesinya. Ia memiliki integritas kepribadian, berpegang 
teguh pada prinsip-prinsip kebenaran sesuai dengan kode etik profesi. Dalam menjalankan profesinya, ia akan menghindari konflik kepentingan dan lebih mengutamakan kepentingan lembaga". ${ }^{5}$

Di tengah kemajuan zaman dengan iklim kompetitifnya, profesionalitas setiap individu yang terlibat dalam pelayanan perumahsakitan merupakan sebuah keniscayaan. Jika tidak diperhatikan, mereka akan tertinggal dari para "pesaing"-nya, dan akibatnya akan terabai dari masyarakat.

\section{Hubungan Hukum Gereja dan Rumah Sakit yang Berbasis Gerejawi}

Konsep Gereja sebagai badan hukum adalah konsep dari sudut pandang institusional dalam gereja6. Pandangan institusional ini mendefinisikan Gereja menurut strukturstrukturnya yang kelihatan, khususnya hak-hak dan wewenang dari para pejabat gereja serta para jemaatnya atau anggota gereja. Gereja sebagaimana badan hukum yang lain maka memiliki struktur yang bertindak sebagai representasi gereja dalam hukum.

Gereja dipandang sebagai suatu perkumpulan yang berdiri dengan status badan hukum. Status tersebut berdasarkan Keputusan Raja tanggal 29 Juni 1925 No. 80 (Staatsblad 1927 No. 156, 157, dan 532) tentang Regeling van de Rechpositie der Kerkgenootschappen (Peraturan Kedudukan Hukum Perkumpulan Gereja), sehingga Gereja atau Perkumpulan Gereja, termasuk bagian-bagian yang berdiri sendiri, dan dianggap sebagai badan hukum. Dari sini terlihat bahwa Lembaga Gereja adalah suatu badan hukum berbentuk perkumpulan. Perkumpulan merupakan salah satu jenis dari Organisasi Kemasyarakatan berbentuk badan hukum. ${ }^{7}$

Sedangkan rumah sakit adalah badan hukum pengelola rumah sakit yang dapat didirikan oleh badan hukum publik dan swasta. ${ }^{8}$ Untuk rumah sakit publik, maka dapat dikelola oleh Pemerintah, Pemerintah Daerah, dan badan hukum yang bersifat nirlaba. Adapun untuk rumah sakit yang didirikan oleh swasta sebagaimana yang dimaksud pada ayat (2) a quo harus berbentuk badan hukum. Selanjutnya dipertegas lagi dalam Pasal 20 ayat (1) UU Rumah Sakit. Dalam Pasal 21 UU Rumah Sakit disebutkan bahwa untuk rumah sakit privat dikelola oleh badan hukum dengan tujuan profit yang berbentuk Perseroan Terbatas atau Persero.

Pada rumah sakit yang berbasis gereja, bentuk hukum badan hukum pengelola akan tepat manakala berbentuk yayasan. Kedudukan gereja dalam konteks ini adalah sebagai pendiri lembaga rumah sakit Kristen.

5 Cicih Bhakti Purnamasari, Mora Claramita, Yayi Suryo Prabandari, 'Pembelajaran Profesionalisme Kedokteran dalam Persepsi Instruktur dan Mahasiswa' (2015) 4 Jurnal Pendidikan Kedokteran Indonesia 21, 23.

$6 \quad$ Dulles Avery, Model-Model Gereja (1990) Nusa Indah 33.

7 Victorianus M.H. Randa Puang, Tinjauan Yuridis Gereja Sebagai Badan Hukum Mempunyai Hak Milik atas Tanah (Softmedia 2012) 201.

$8 \quad$ Pasal 7 ayat 2 UU No. 44 Tahun 2009 tentang Rumah Sakit. 
Kedudukan gereja dan representasinya dapat dilihat dari memenuhi tidaknya UU Nomor 16 Tahun 2001 tentang Yayasan sebagaimana diubah dengan UU Nomor 28 Tahun 2004 terutama Bab II, Pasal 9 dan Bab VI, Pasal 28. Secara yuridis pendiri yayasan ini dimandatkan kepada representasinya yang adalah organ dalam yayasan penyelenggara perumahsakitan. Personalia dari yayasan ini diutus dan diberi mandat oleh gereja sebagai pendiri. Organ yang terdiri dari pembina, pengawas dan pengurus yayasan mendapatkan mandat dari gereja. Ada hukum gerejawi dan hukum nasional yang menjadi sumber hukum dalam hubungan hukum pada lembaga ini. Pemandatan gerejawi kepada organ yayasan pengelola rumah sakit pada dasarnya tidak melanggar ketentuan undang-undang. Organ pengurus pada yayasan pengelola, dalam menjalankan fungsinya sebagaimana diatur dalam UU Nomor 16 Tahun 2001 tentang Yayasan, Bab VI, Pasal 28 ayat (2) yang merupakan representasi gereja, secara moral personalia yang diutus oleh gereja dan menundukkan diri kepada gereja pengutus. Dengan demikian organ yayasan secara yuridis patuh pada aturan-aturan hukum dan secara moral menundukkan diri pada hukum gereja.

Nilai-nilai yang terkandung di dalam hukum gereja merupakan representasi gereja untuk memiliki tanggung jawab menyemaikan, mengimplementasikan, serta menginternalisasikan nilainilai yang diturunkan dari nilai-nilai (core values) gereja pendiri. Beberapa hal yang penting dalam nilai tersebut adalah karakter kristen, bisnis dengan etika kriten, memelihara keharmonisan, mengembangkan pelayanan berkualitas, dan bekerja dalam budaya pembelajaran. Nilai-nilai ini diupayakan menjadi budaya yang terinternalisasikan dalam diri setiap insan yang terlibat dalam rumah sakit.

\section{Aspek Hukum Pelayanan Rumah Sakit}

Setiap orang berhak hidup sehat serta memperoleh pelayanan kesehatan sebagaimana diatur dalam Pasal $28 \mathrm{H}$ UUD NRI 1945. Negara bertanggungjawab atas penyediaan pelayanan kesehatan dan fasilitas pelayanan umum yang layak (Pasal 34 ayat 3 UUD NRI 1945). UU Nomor 40 Tahun 2004 tentang SJSN menegaskan bahwa; Jaminan kesehatan diselenggarakan secara nasional berdasarkan prinsip asuransi sosial dan prinsip ekuitas. Setiap orang mempunyai hak dalam memperoleh pelayanan kesehatan yang aman, bermutu, dan terjangkau sebagaimana di atur dalam UU No 36/2009 tentang kesehatan, pasal 5 ayat 2). 


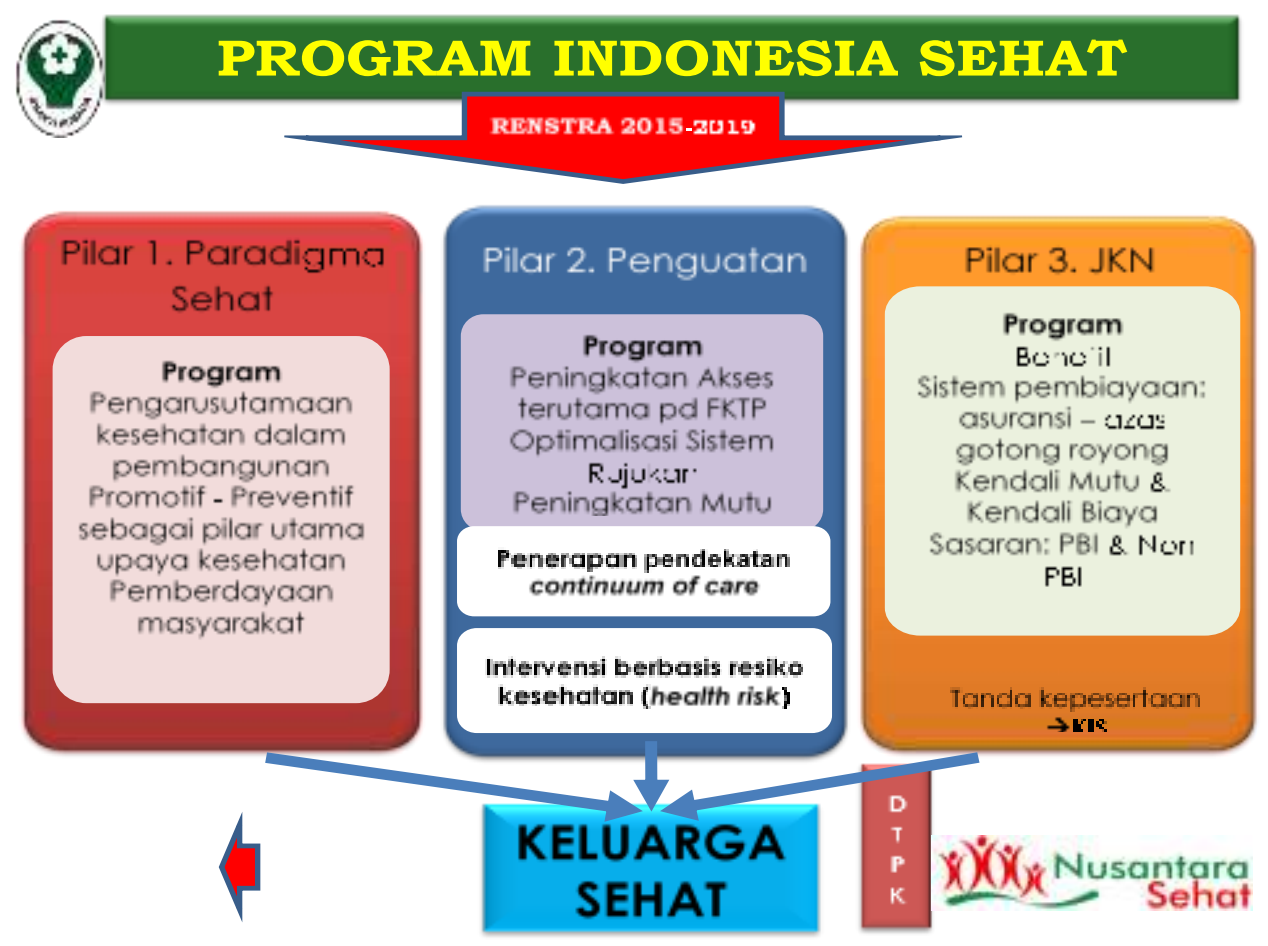

Gambar 1. Penjabaran Visi \& Misi Presiden Menjadi Program Indonesia Sehat ${ }^{9}$

Program Indonesia Sehat menjadi program utama Pembangunan Kesehatan yang kemudian direncanakan pencapaiannya melalui Rencana Strategis Kementerian Kesehatan Tahun 2015-2019, yang ditetapkan melalui Keputusan Menteri Kesehatan Nomor HK.02.02/Menkes / 52/2015. Dalam sasaran pokok Rencana Pembangunan Jangka Menengah Nasional 2015-2019 disebutkan yaitu: (1) meningkatnya status kese-hatan dan gizi ibu dan anak, (2) meningkatnya pengendalian penyakit, (3) meningkatnya akses dan mutu pelayanan kesehatan dasar dan rujukan terutama di daerah terpencil, tertinggal dan perbatasan, (4) mening- katnya cakupan pelayanan kesehatan universal melalui Kartu Indonesia Sehat dan kualitas pengelolaan SJSN kesehatan, (5) terpenuhinya kebutuhan tenaga kesehatan, obat dan vaksin, serta (6) meningkatnya responsivitas sistem kesehatan. Program Indonesia Sehat dilaksanakan dengan menegakkan tiga pilar utama, yaitu: (1) penerapan paradigma sehat, (2) penguatan pelayanan kesehatan, dan (3) pelaksanaan jaminan kesehatan nasional (JKN).

Pelayanan Perumahsakitan dalam UU Kesehatan disebutkan sebagai setiap upaya yang diselenggarakan sendiri atau secara bersama-sama

$9 \quad$ Untung Suseno Sutarjo, Pedoman Umum Program Indonesia Sehat Dengan Pendekatan Keluarga (Kementerian Kesehatan Republik Indonesia 2016) 1. 
dalam suatu organisasi untuk memelihara dan meningkatkan kesehatan, mencegah dan menyembuhkan penyakit serta memulihkan kesehatan, perorangan, keluarga, kelompok ataupun masyarakat. Berdasarkan bentuk pelayanan kesehatan yang diatur dalam Pasal 52 ayat (1) UU Kesehatan terdiri dari:

1. Pelayanan kesehatan perseorangan (medical service)

Pelayanan ini banyak diselenggarakan oleh perorangan secara mandiri (self care), dan keluarga (family care) atau kelompok anggota masyarakat. Tujuan untuk menyembuhkan penyakit dan memulihkan kesehatan perorangan dan keluarga. Pelayanan kesehatan ini dilaksanakan pada institusi pelayanan kesehatan seperti rumah sakit, klinik bersalin dan praktik mandiri.

2. Pelayanan kesehatan masyarakat (public health service)

Pelayanan ini biasanya diselenggarakan kelompok dan masyarakat. Pelayanan kesehatan ini bertujuan untuk memelihara dan meningkatkan kesehatan yang mengacu pada tindakan promotif dan preventif. Upaya pelayanan masyarakat tersebut dilaksanakan pada pusatpusat kesehatan masyarakat tertentu seperti pukesmas.

Berdasarkan Pasal 52 UU Kesehatan, kegiatan pelayanan kesehatan dilakukan secara paripurna yang terdari dari:

1. Pelayanan kesehatan promotif

2. Pelayanan kesehatan preventif

3. Pelayanan kesehatan kuratif

4. Pelayanan kesehatan rehabilitatif
Lembaga rumah sakit adalah lembaga tugas pelayanan kesehatan untuk seluruh masyarakat. Rumah sakit adalah suatu sarana yang merupakan bagian dari sistem pelayanan kesehatan yang menjalankan rawat inap, rawat jalan, dan rehabilitasi berikut segala penunjangnya.

Pasal 1 butir 1 UU Kesehatan menjelaskan bahwa rumah sakit adalah institusi pelayanan kesehatan yang menyelenggarakan pelayanan kesehatan perorangan secara paripurna, serta menyediakan pelayanan rawat jalan, rawat inap, dan gawat darurat. Di dalam pelayanannya jenis pelayanan yang diberikan rumah sakit dikatagorikan sebagai rumah sakit umum dan rumah sakit khusus. Sedangkan untuk pengelolaan rumah sakit dibagi atas rumah sakit publik bersifat nirlaba dan rumah sakit privat bertujuan profit.

Rumah sakit dan lembaga layanan kesehatan merupakan sebuah institusi atau lembaga yang pada awalnya adalah lembaga sosial, yang bertujuan untuk membantu masyarakat terutama kalangan yang tidak mampu. Berikut ini dijelaskan secara singkat mengenai pengertian rumah sakit oleh Anthony Giddens yang mengemukakan bahwa pelayanan kesehatan di Indonesia telah bergeser dari public goods menjadi private goods sehingga pemenuhan kepuasan pasien semakin lama semakin kompleks dan semua rumah sakit dan lembaga layanan kesehatan bersaing untuk menarik pasien.

Konsekuensinya penyelenggaraan rumah sakit dan layanan kesehatan pada zaman modern tidak sesederhana seperti dulu lagi karena kebutuhan untuk mengelola rumah sakit dengan 
prinsip bisnis tidak dapat lagi dielakkan.

\section{Tantangan Regulasi dalam Era Sistem Jaminan Kesehatan}

Beberapa sumber hukum yang harus diperhatikan, bagi pengelola rumah sakit berbasis gereja dalam era Sistem Jaminan Kesehatan adalah sebagai berikut:

1. UU Nomor 40 Tahun 2004 tentang Sistem Jaminan Sosial Nasional.

2. UU Nomor 29 Tahun 2004 tentang Praktik Kedokteran.

3. UU Nomor 36 Tahun 2009 tentang Kesehatan.

4. UU Nomor 44 Tahun 2009 tentang Rumah Sakit.

5. UU Nomor 24 Tahun 2011 tentang Badan Penyelenggara Jaminan Sosial.

Dalam era Sistem Jaminan Kesehatan ini maka dalam penyelenggaraan rumah sakit akan menghadapi banyak tantangan. Adapun beberapa tantangan yang menjadi perhatian yaitu:

a. Mematuhi regulasi yang terus berubah dan semakin ketat.

b. Pada saat yang sama harus juga menyesuaikan dengan beberapa perubahan strategis di bidang kesehatan.

c. Menyelesaikan permasalahan kesehatan di era desentralisasi.

d. Program JKN.

e. Pola hubungan Dokter/Nakes dengan Pasien yang bergeser dari paternalistik menjadi kontraktual yang kondisi ini mempengaruhi hubungan dalam pelayanan kesehatan.
Dalam perkembangannya praktek bisnis rumah sakit ini berjalan dalam 2 (dua) arah yang serba ambigu. Apakah dalam pelayanan sosial atau komoditas pasar. Praktek bisnis perumahsakitan yang meletakkan pelayanan sebagai komoditas sosial tentu saja tidak akan comply dengan pelayanan berbasis komersial. Ambil contoh; BPJS merupakan adopsi dari jaminan sosial. Penggunaan teknologi tinggi, sistem yang ketat dan mengedepankan nilainilai efisiensi dan efektifitas serta kelanggengan layanan, merupakan nilai-nilai yang ditemukan pada praktek perumahsakitan yang berbasis komoditas. Bila rumah sakit dihadapkan dengan kekuatan keuangan/ pendanaan rumah sakit baik dari pasien maupun dari BPJS yang terbatas, dengan kepuasan pasien yang berbasis pada mutu dalam sebuah sistem jaminan kesehatan nasional, maka dapat digambarkan di bawah ini:

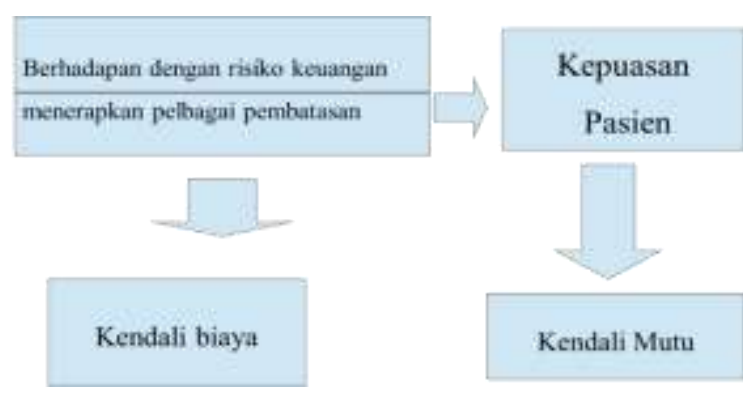

Gambar 2. Sistem Jaminan Kesehatan Nasional

Jika diperhatikan pada gambar di atas sistem jaminan kesehatan nasional saat ini telah berhadapan dengan risiko keuangan untuk mencapai pada titik tertinggi kepuasan pasien. Karena kepuasan pasien menjadi kendali mutu dari sebuah rumah sakit. Sehingga perlu diterapkannya berbagai pembata- 
san seperti mengendalikan biaya pada rumah sakit.

Sedangkan untuk mendirikan sebuah rumah sakit terdapat regulasi yang sangat ketat yang harus dipenuhi, yaitu;

1. Ijin mendirikan rumah sakit

2. Ijin operasional

a. Memiliki izin mendirikan

b. Saraba prasarana

c. Peralatan

d. Sumber daya manusia

e. Administrasi manajemen

\section{Akreditasi}

Selanjutnya mengenai akreditasi pada rumah sakit yang diatur dalam UU Nomor 44 Tahun 2009 dan Permenkes Nomor 34 Tahun 2017 yang harus diperhatikan adalah upaya peningkatan mutu dan pasien, integrasi pendidikan kesehatan dalam pelayanan rumah sakit dan disusun mengacu pada prinsip-prinsip penyusunan standar dari International Society for Quality in Healthcare (ISQua), standar akreditas versi 2012, standar akreditas JCI edisi 4 dan serta peraturan perundangundangan yang berlaku.

\section{Filantropi pada Rumah Sakit Berbasis Gerejawi dalam Perspektif Hukum}

\section{Sistem Kesehatan Nasional (SKN) dan Sistem Kesehatan Daerah (SKD)}

Pasal 2 ayat (2) Peraturan Presiden No. 72 tahun 2012 tentang Sistem Kesehatan Nasional, mengamanatkan bahwa pengelolaan kesehatan harus dilakukan secara berjenjang baik di pusat maupun di daerah dengan memperhatikan otonomi daerah dan otonomi fungsional di bidang kesehatan. Pasal tersebut secara yuridis memiliki dua arti. Pertama, bagi daerah, pembangunan kesehatan tidak cukup hanya dengan menggunakan SKN. Daerah perlu memiliki acuan dan pedoman dalam pembangunan kesehatan daerah yang sesuai dengan kondisi spesifik, kebutuhan dan permasalahan kesehatan di masingmasing daerah. Dengan kata lain, daerah perlu memiliki SKD. Kedua, konstruksi regulasi yang diatur dalam SKD harus sesuai dengan otonomi fungsional pemerintah daerah di bidang kesehatan. Pembagian kewenangan antara pemerintah pusat dan pemerintah daerah di bidang kesehatan diatur dalam UU Nomor 23 Tahun 2014 tentang Pemerintahan Daerah sebagaimana terakhir di ubah dengan UU Nomor 9 Tahuan 2015. Pemerintah daerah yang akan menyusun SKD sebagai regulasi daerah, susbtansi yang diatur dalam SKD tidak boleh bertentangan dengan kewenangan pemerintah pusat.

Manfaat jaminan kesehatan diberikan pada fasilitas kesehatan milik Pemerintah atau swasta yang menjalin kerjasama dengan BPJS (UU Nomor 40 Tahun 2004 Pasal 23). Berdasarkan kontrak dengan BPJS, Fasilitas Layanan Kesehatan bertanggung jawab atas pemeliharaan sejumlah peserta tertentu sesuai dengan kontrak/kerjasama yang disepakati. Sebagai contoh jika satu dokter dapat melayani 500-600 kepala keluarga dengan pembayaran berkapasitas. 


\section{Sistem Pelayanan Kesehatan dan Filantropi}

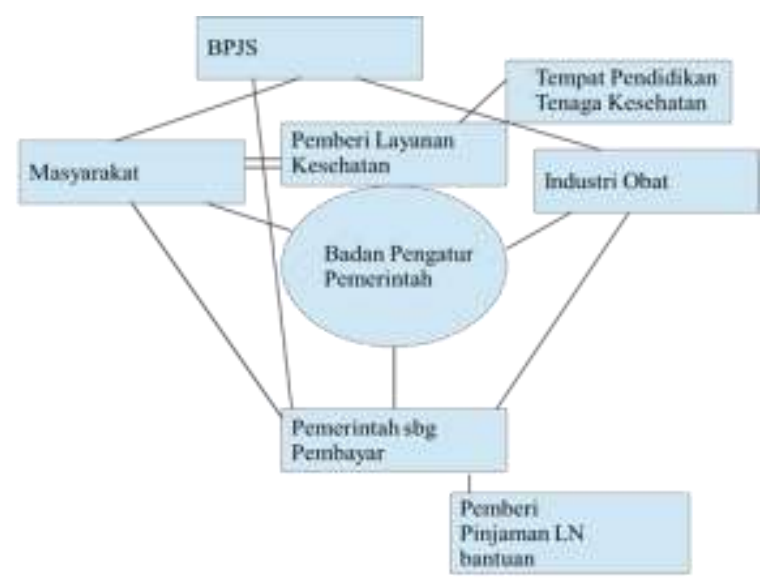

Gambar 3. Komponen Sistem Pelayanan Kesehatan (Diadaptasi dari: Public Health Forum di London School of Hygiene and

Tropical Medicine, tahun 1998).

Dari gambar tersebut dapat dilihat bahwa Badan Pengatur Pemerintah memiliki peranan yang sangat kuat dalam memberikan pengawasan dan penanggung jawab dalam pelayanan kesehatan. Sebagai sebuah sistem, komponen badan pengatur merupakan komponen penting yang terhubung dengan komponen-komponen yang lain.

Adapun asuransi, pabrik obat dan fasilitas layanan, industri peralatan dan teknologi kesehatan dan industri finansial akan menjadi penentu dalam sistem pelayanan kesehatan.

Mana kala dikaitkan dengan perkembangan industri 4.0 maka kemampuan dalam mengelola "big data" dan platform pengelolaan finansial akan lahir sebagai jawaban pada skala bisnis kesehatan masa depan.

Lalu bagaimana dengan rumah sakit berbasis gereja yang bertujuan Sosial? Pada bagan di atas, rumah sakit ini terletak pada komponen pemberi layanan kesehatan bersama-sama dengan rumah sakit lain yang diselenggarakan oleh pemerintah sebagai badan hukum publik maupun rumah sakit yang diselenggarakat oleh swasta (privat). Sebagai pemberi layanan kesehatan, rumah sakit ini terhubung dengan masyarakat yang dilayaninya dibidang kesehatan dan juga terhubung dengan BPJS sebagai badan penyelenggara jaminan kesehatan dimana sebagian besar pendapatan rumah sakit saat ini berasal. Dimana melayani masyarakat yang pada tahun 2019 ditargetkan seluruhnya menjadi peserta BPJS, maka hubungan hukum rumah sakit dengan BPJS juga akan semakin kuat di tahun 2019 ini.

Namun demikian, apakah hubungan rumah sakit berbasis gereja dengan masyarakat akan sama dengan hubungan masyarakat dengan rumah sakit yang diselenggarakan oleh badan penyelenggara lain, seperti halnya pemerintah daerah, pusat maupun swasta? Untuk menjawab pertanyaan tersebut dapat dilihat dari filantropi sebagai inti dari layanan kesehatan gereja dan juga rumah sakit berbasis gereja yang bersifat sosial ini, yang hadir dan langgeng didasarkan pada pengalaman rohani yang dimiliki manusia. Hal tersebut gegayutan dengan realitas manusia sebagai mahluk sosial (homo homoni socius), menginginkan terwujudnya masyarakat ideal dan masyarakat sejahtera. Karena pada dasarnya, manusia secara filsafati terkandung makna didalamnya sebagai animal rationale, geist in welt (badani), dan 
esprit incarne (Driyarkara). ${ }^{10}$ Lebih lanjut manusia secara filsafati di atas, dapat didefinisikan sebagai berikut.

a. Definisi klasik menyatakan bahwa manusia adalah animal rationale atau hewan berbudi yang merupakan bentuk aksi-reaksi biologis ada persamaan, walaupun hanya dalam suatu momen tertentu saja dari totalitas atau keseluruhan. Namun demikian dalam aksi reaksi psikologis, tentu saja manusia dengan hewan sama sekali berbeda.

b. Geist-in-welt; bahwa manusia dipandang sebagai barang di dunia yang badani, oleh karenanya dalam manusia tersebut memiliki sifatsifat badani juga;

c. Esprit incarne; bahwa manusia merupakan roh yang telah menjelma menjadi daging. Maksudnya bahwa manusia betul- betul bersifat jasmani, stoffelijk. ${ }^{11}$

Sedangkan menurut Notohamidjojo, manusia meliputi objek, subjek dan relasi. ${ }^{12}$ Lembaga kesehatan ini merupakan tempat manusia-manusia yang memiliki tanggung jawab rohani dan tanggung jawab sosial tersebut.

Filantropi diibaratkan sebagai anggur lama dalam botol baru. Istilah filantropi tergolong baru, tapi praktiknya sudah sudah dilakukan ratusan tahun. Filantropi adalah bagian dari ajaran keagamaan yang dikenal dalam bentuk kolekte, persepuluhan; dan tradisi atau budaya dalam bentuk jimpitan, patungan, yang berkaitan dengan kedermawanan. Hukum pada dasarnya tidak mengatur secara ketat mengenai hal ini.

Namun dalam perkembangannya pada filantropi modern, pemberian dana kesehatan yang bersifat suka rela ini sering kali diikatkan dalam sebuah kontrak. Sebuah kontrak kerjasama yang terbentuk terdiri dari tiga pihak yaitu donatur sebagai pihak yang memberikan dana secara suka rela, rumah sakit sebagai pihak kedua yang menerima dana dan masyarakat (beneficiary) sebagai pihak ketiga penerima manfaat dari dana filantropi. Selayaknya sebuah kontrak modern, maka kontrak kerjasama filantropi ini memuat klausul-klausul yang rigid dengan memiliki ciri khusus yang tidak dimiliki oleh kontrak-kontrak lainnya. Nilai-nilai kemanusiaan, perlindungan bagi perempuan dan anak, gender dan rupa-rupa politik lembaga pemberi dana filantropi yang dimuatkan dalam kontrak sehingga mengikat bagi rumah sakit sebagai penerima dana untuk kepentingan beneficiary.

Selain filantropi diberikan berdasarkan kesukarelaan dan kontrak di atas, maka filantropi juga berkembang dalam perkembangan bisnis korporasi dalam bentuk Coorporate Social Responsibility (CSR). CSR adalah

"corporate social responsibility involves the conduct of a business so that it is economically profitable, law abiding, ethical and socially supportive. To be socially responsible then means that profitability and obedience to the law are foremost conditions when discussing the

\footnotetext{
10 Dyah Hapsari Prananingrum, 'Telaah terhadap Esensi Subyek Hukum: Manusia dan Badan Hukum' (2014) 8 Refleksi Hukum: Jurnal Ilmu Hukum 73, 75.

11 Ibid

$12 \quad$ Ibid.
} 
firm's ethics and the extent to which it supports the society in which it exists with contributions of money, time and talent"13 (p.608)
Selanjutnya Carroll menggambarkan CSR tersebut dalam sebuah piramida responsibilitas sebagai berikut.

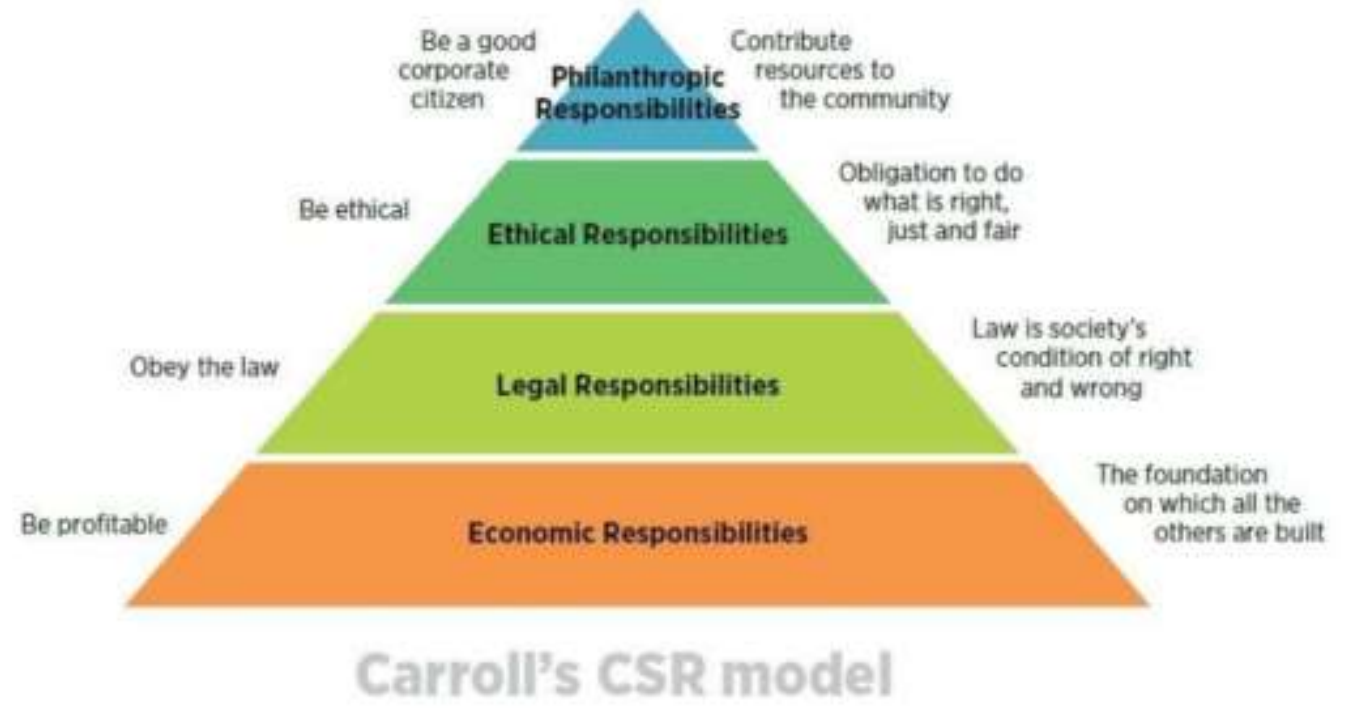

Gambar 4. The Pyramid of Corporate Social Responsibility (Carroll, 1991) ${ }^{14}$

Konsep ini dikembangkan oleh Archie B. Carroll yang memberikan justifikasi teoritis dan logis mengapa sebuah perusahaan perlu menerapkan CSR bagi masyarakat di sekitarnya. Dalam pandangan Carroll, CSR adalah puncak piramida yang erat terkait, dan bahkan identik dengan tanggung jawab filantropis. Adapun 4 (empat) bentuk model tanggung jawab dalam CSR dikemukakan oleh Hartman, Des Jardins dan Macdonald, dalam buku Business Ethics, Decision making for Personal Integrity \& Social Responsibility Third Edition bisa membantu memilah seperti apa implementasi CSR itu. ${ }^{15}$

1. Tanggung Jawab Ekonomis
Kata kuncinya adalah: make a profit. Motif utama perusahaan adalah menghasilkan laba. Laba adalah pondasi perusahaan. Perusahaan harus memiliki nilai tambah ekonomi sebagai prasyarat agar perusahaan dapat terus hidup (survive) dan berkembang.

2. Tanggung Jawab Legal

Kata kuncinya: obey the law. Perusahaan harus taat hukum. Dalam proses mencari laba, perusahaan tidak boleh melanggar kebijakan dan hukum yang telah ditetapkan pemerintah.

3. Tanggung Jawab Etis

Kata kuncinya: be ethical. Perusahaan memiliki kewajiban

13 Archie B. Carroll, Revisiting Carroll's CSR Pyramid (2016) International Journal of Corporate Social Responsibility 1, 1.

$14 \quad$ Ibid., 8.

15 Bandingkan dengan Laura P. Hartman, Joseph DesJardins dan Chris MacDonald, Business Ethics, Decision making for Personal Integrity \& Social Responsibility Third Edition (The McGraw-Hill Companies, Inc. 2014) 217-228. 
untuk menjalankan praktek bisnis yang baik, adil dan fair. Normanorma masyarakat perlu menjadi rujukan bagi perilaku organisasi perusahaan.

4. Tanggung Jawab Filantropis

Kata kuncinya: be a good citizen. Selain perusahaan harus memperoleh laba, taat hukum dan berperilaku etis, perusahaan dituntut agar dapat memberi kontribusi yang dapat dirasakan secara langsung oleh masyarakat. Tujuannya adalah untuk meningkatkan kualitas kehidupan semua.

Bila digambarkan secara jelas maka letak dana filantropi baik yang lahir dari kontrak filantropi maupun CSR, dalam pelayanan rumah sakit gerejawi adalah sebagai berikut:

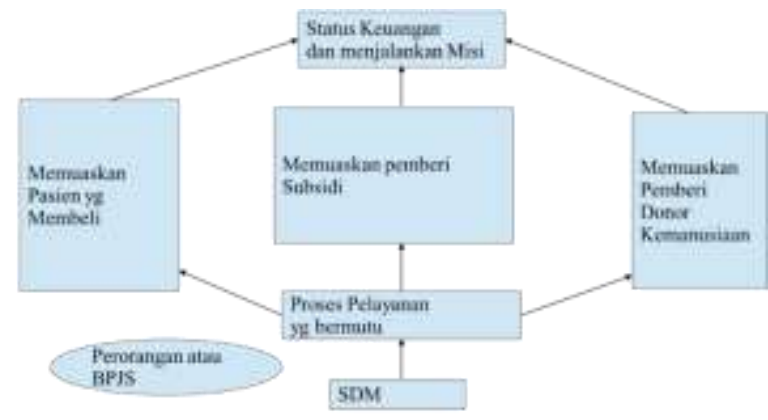

Gambar 5. Letak Dana Filantropi

Pada gambar di atas dijelaskan bahwa sumber daya manusia mempunyai peranan yang sangat kuat dalam memberikan pelayanan yang bermutu seperti dalam pelayanan pemberi donor kemanusiaan, memuaskan pasien yang membeli, serta memuaskan pembeli subsidi sehingga mendapat keuntungan dimana keuntungan tersebut dapat dijalankan sesuai dengan misi.

\section{PENUTUP}

Kegiatan rumah sakit berbasis gereja mendasarkan pada sebuah ajaran atau doktrin yang dikenal dengan good samaritan atau orang Samaria yang baik hati. Rumah sakit berposisi sebagai orang samaria yang memberikan bantuan/layanan kesehatan bagi masyarakat yang membutuhkan. Saat masyarakat sebagai beneficiary membutuhkan pelayanan kesehatan, negara tidak juga dapat cukup memenuhi kebutuhan kesehatan seluruh masyarakat melalui layanan rumah sakit, maka di sisi inilah rumah sakit berbasis gerejawi hadir memberikan layanan tersebut.

Pendapatan rumah sakit yang terutama bersumber dari kegiatan operasional melalui penyelenggaraan pemeriksaan, pengobatan dan perawatan. Namun sumber daya ini tentu tidaklah mencukupi, maka dilakukan kegiatan filantropi, yang secara yuridis terbentuk dari hubungan hukum kontraktual. Filantropi yang menjadi salah satu penopang pendanaan kegiatan rumah sakit berbasis gerejawi, lahir dari tradisi maupun ajaran agama, yang terus berkembang seiring dengan kebutuhan masyarakat akan layanan kesehatan yang terus bertambah dan tidak dapat dipenuhi oleh negara maupun pelaku usaha. Kegiatan filantropi guna membiayai rumah sakit sebagaimana dipaparkan di atas merupakan salah satu wujud pembiayaan tidak mengikat sebagaimana yang diatur dalam UU Rumah Sakit khususnya dalam Pasal 48 ayat (1). 


\section{DAFTAR BACAAN}

\section{Buku}

Avery, D., Model-Model Gereja (Nusa Indah 1990).

Bastian, I., Akuntansi Kesehatan (Gelora Aksara Pratama 2008).

Prananingrum, Dyah H., Hukum Yayasan di Indonesia: Kajian Yuridis dan Filisofis (Genta Publishing 2016).

Puang, Victorianus M. H. R., Tinjauan Yuridis Gereja Sebagai Badan Hukum Mempunyai Hak Milik atas Tanah (Softmedia 2012).

Sutarjo, Untung S., Pedoman Umum Program Indonesia Sehat Dengan Pendekatan Keluarga (Kementerian Kesehatan Republik Indonesia 2016).

Hartman, Laura P., DesJardins J., dan MacDonald C., Business Ethics, Decision making for Personal Integrity \& Social Responsibility Third Edition (The McGraw-Hill Companies, Inc. 2014) 217-228.

\section{Artikel Jurnal}

Carroll, Archie B., 'Revisiting Carroll's CSR Pyramid' (2016) International Journal of Corporate Social Responsibility.

Purnamasari, Cicih B., Claramita, M., Prabandari, Yayi S., 'Pembelajaran Profesionalisme Kedokteran Dalam Persepsi Instruktur dan Mahasiswa' (2015) 4 Jurnal Pendidikan Kedokteran Indonesia.

Prananingrum, Dyah H., 'Telaah terhadap Esensi Subyek Hukum: Manusia dan Badan Hukum' (2014)
8 Refleksi Hukum: Jurnal Ilmu Hukum.

\section{Makalah}

Subandrijo, B., 'Layanan Kesehatan dan Perumahsakitan sebagai Media Kesaksian dan Pelayanan Gerejawi' (Seminar Sinode GKJ-YLPHS, Salatiga, Desember 2018).

\section{Peraturan Perundang-Undangan}

Undang-Undang Dasar Negara Republik Indonesia Tahun 1945.

Undang-Undang Nomor 16 Tahun 2001 tentang Yayasan sebagaimana diubah dengan Undang-Undang Nomor 28 Tahun 2004.

Undang-Undang Nomor 29 Tahun 2004 tentang Praktik Kedokteran.

Undang-Undang Nomor 40 Tahun 2004 tentang Sistem Jaminan Sosial Nasional.

Undang-Undang Nomor 36 Tahun 2009 tentang Kesehatan.

Undang-Undang Nomor 44 Tahun 2009 tentang Rumah Sakit.

Undang-Undang Nomor 24 Tahun 2011 tentang Badan Penyelenggara Jaminan Sosial.

Undang-Undang Nomor 23 Tahun 2014 tentang Pemerintahan Daerah sebagaimana diubah dengan UU Nomor 9 Tahun 2015.

Peraturan Presiden Nomor 72 Tahun 2012 tentang Sistem Kesehatan Nasional. 